\title{
KORELASI KADAR KOLESTEROL DENGAN KEJADIAN DIABETES MELLITUS TIPE 2 PADA LAKI-LAKI
}

\author{
Rahayu Anggraini \\ Prodi D-IV Analis Kesehatan, Fakultas Kesehatan, Universitas Nahdlatul Ulama Surabaya \\ e-mail: : anggrek@unusa.ac.id ${ }^{1}$
}

\begin{abstract}
Type 2 diabetes is one of the most common chronic diseases in the world. It is estimated that more than 140 million people worldwide are currently suffering from diabetes, and by 2025, an estimated more than 300 million people will suffer from the disease. The purpose of this study was to evaluate the correlation of cholesterol with the incidence of Diabetes Mellitus disease. The type of this research is observational with cross-sectional analytic approach and done in PLN employees, total are 112 people of which are mens. All participants underwent biochemical analysis of fasting blood sugar (BSN) and 2 hours PP (post prandial), and total cholesterol level test. Determination of glucose by glucose oxidase method and cholesterol level by CHOD-PAP method. The mean results in normal cholesterol (<200 mg/dl) obtained BSN = $73 \mathrm{mg} / \mathrm{dl}$, 2 Hours PP = $92 \mathrm{mg} / \mathrm{dl}$, and in abnormal cholesterol ( $>200 \mathrm{mg} / \mathrm{dl}$ ) mean BSN $=81 \mathrm{mg} / \mathrm{dl}$, 2 hours $P P=109 \mathrm{mg} / \mathrm{dl}$, in independent T test with $p=0001$ in both groups of different cholesterol levels. Results of the Pearson's correlation test, there was a significant positive correlation between GDP and cholesterol levels $(r=0.262, p=0.005)$, and 2 hours PP and cholesterol levels $(r=0.258, p=0.006)$. Conclusions: There was a significant positive correlation between 2 hours PP and cholesterol levels. This study shows there is a correlation of cholesterol levels that develop diabetes mellitus type 2.
\end{abstract}

Keywords: Cholesterol levels, Blood Suger Nuchter (BSN), Blood suger 2 hours post pandial, Diabetes mellitus type 2.

Abstrak: Diabetes tipe 2 adalah salah satu penyakit kronis yang paling umum di dunia. Diperkirakan lebih dari 140 juta orang di seluruh dunia saat ini menderita diabetes, dan pada tahun 2025, diperkirakan lebih dari 300 juta orang akan menderita penyakit ini. Tujuan penelitian ini adalah untuk mengevaluasi korelasi kadar kolesterol dengan kejadian penyakit Diabetes Mellitus tipe 2. Jenis penelitian adalah observasional dengan pendekatan cross-sectional analitik yang dilakukan pada karyawan PLN laki-laki sebanyak 112 orang. Semua peserta menjalani analisis biokimia gula darah puasa (BSN) dan 2 jam PP (post prandial), serta uji kadar kolesterol. Penentuan kadar glukosa dengan metode glucose oxidase dan kadar kolesterol dengan metode $C H O D-P A P$. Hasil penelitian pada pasien normal kolesterol didapat nilai rata-rata $\mathrm{BSN}=73 \mathrm{mg} / \mathrm{dl}, 2 \mathrm{Jam} \mathrm{PP}=92 \mathrm{mg} / \mathrm{dl}$, dan pada pasien abnormal kolesterol nilai rata-rata $\mathrm{BSN}=81 \mathrm{mg} / \mathrm{dl}$, $2 \mathrm{Jam} \mathrm{PP}=109 \mathrm{mg} / \mathrm{dl}$ dengan uji " $\mathrm{T}$ " bebas didapat nilai $\mathrm{p}=0001$. Hasil dengan uji korelasi Pearson's, ada korelasi positif yang signifikan antara kadar BSN dengan kadar kolesterol ( $\mathrm{r}=$ 0,262, $\mathrm{p}=0,005)$, dan pada kadar 2 jam PP dengan kadar kolesterol $(\mathrm{r}=0,258, \mathrm{p}=0,006)$. Kesimpulan: ditemukan korelasi positif yang signifikan antara kadar BSN, 2 jam PP, dan kadar kolesterol serum. Penelitian ini menunjukkan ada korelasi kadar kolesterol yang tinggi ( $>200 \mathrm{mg} / \mathrm{dl})$ dapat mengembangkan penyakit diabetes mellitus type 2 .

Kata kunci: Kadar kolesterol, kadar gula darah puasa, Kadar gula darah 2 jam PP, Diabetes Mellitus Tipe 2.

\section{PENDAHULUAN}

Glukosa dalam aliran darah meningkat tidak normal menyebabkan haus yang tak terkendalikan dan sering buang air kecil. Ketidakmampuan tubuh menyimpan atau menggunakan glukosa menyebabkan rasa lapar sehingga meningkatkan berat badan. Diabetes terjadi saat tubuh tidak menghasilkan cukup hormon insulin atau insulin yang diproduksi normal namun kurang efektif dan sering terjadi pada orang berusia di atas 40 tahun, 
karenanya hampir $90 \%$ penyakit diabetes mellitus jatuh pada type 2 (Chaterjee MN, 2005).

Menurut Federasi Diabetes Internasional, diperkirakan ada 194 juta orang penderita Diabetes pada tahun 2003 dan sekitar $2 / 3$ orang berada di negara berkembang (IDF, 2003). Diabetes melitus tipe II dikaitkan dengan sekelompok kelainan lipid plasma dan lipoprotein yang saling terkait. Ini semua diketahui sebagai prediktor terjadi penyakit jantung koroner.

Atherosclerosis adalah komplikasi utama akibat kadar kolesterol yang tinggi (dislipidemia), sehingga dianggap bertanggung jawab akan terjadinya peningkatan morbiditas dan mortalitas di Indonesia. Studi epidemiologis telah menunjukkan bahwa kadar kolesterol yang tinggi pada pasien diabetes melitus tipe- 2 dan pasien non-diabetes tanpa riwayat penyakit kardiovaskular, memiliki risiko kejadian kardiovaskular yang sama. Pada obesitas, sintesis kolesterol dan omset dapat meningkat tajam dan efisiensi penyerapan kolesterol menurun. Dengan demikian, metabolisme kolesterol sering dikaitkan dengan diabetes, sebagai faktor yang bertanggung jawab atas perubahan yang perlu diamati. Berdasarkan data di atas, peneliti mencoba meneliti kadar kolesterol yang tinggi dengan kejadian Diabetes Mellitus tipe 2 pada laki-laki.

\section{Diabetes Mellitus tipe 2}

Diabetes tipe 2 adalah salah satu penyakit kronis yang paling umum di dunia. Diperkirakan lebih dari 140 juta orang di seluruh dunia saat ini menderita diabetes, dan pada tahun 2025, diperkirakan lebih dari 300 juta orang akan menderita penyakit ini (World Health Organisasi 1999). Diabetes Mellitus tipe 2 menyumbang sekitar 90\% dari semua kasus diabetes.

Angka prevalensi Diabetes Mellitus di Indonesia berkisar antara 1,4-1,6\%, kecuali di Manado (6\%). Penelitian di kelurahan Kayuputih yang merupakan contoh daerah perkotaan menghasilkan prevalensi sebesar 5,6\%, sedangkan di daerah pedesaan Jawa Barat sebesar 1,1\%. Di Indonesia pasien Diabetes mellitus tipe 2 merupakan diabetes yang paling banyak ditemukan, sedangkan Diabetes mellitus tipe 1 sangat jarang.

Penyebab paling umum morbiditas dan mortalitas pada diabetes mellitus tipe 2 adalah penyakit kardiovaskular. Risiko koroner penyakit arteri adalah dua sampai empat kali lipat, lebih tinggi pada wanita dibandingkan pada pria, dan setelah itu terjadi infark miokard akut, risiko kematian bisa mencapai lebih dari dua kali lipat. Risiko infark miokard sebanding pada pasien nondiabetes (Haffner et al 1998).

Ada beberapa faktor risiko kardiovaskular yang diketahui seperti Diabetes mellitus tipe 2 termasuk hiperinsulinemia, hipertensi, dislipidemia, resistensi insulin dan obesitas, yang kesemuanya dianggap terlibat dalam akselerasi mengembangkan aterosklerosis. Diabetes tipe 2 didefinisikan dengan peningkatan kadar glukosa dalam darah. Dasar molekuler diabetes tipe 2 belum jelas, hasil spekulasi menghasilkan cacat genetik yang menyebabkan resistensi insulin dan kekurangan insulin menyebabkan cacat genetik, sehingga tidak ada gen tunggal atau gen kandidat. Diabetes mellitus tipe 2 telah ditemukan berkontribusi pada etiologi penyakit kardiovaskula (Kahn dan Porte 2001). Umumnya Diabetes mellitus tipe 2 adalah kelainan poligenik, hasil dari beberapa gabungan gen cacat dipengaruhi oleh faktor-faktor lingkungan, semuanya bersamasama menghasilkan sindrom klinis Diabetes mellitus tipe 2 .

\section{Metabolisme lipoprotein pada Diabetes Mellitus Tipe 2}

Diabetes mellitus tipe 2 dikaitkan dengan serum puasa dan postprandial yang tidak normal. Metabolisme lipoprotein Fitur utama dari dislipidemia ini adalah tingkat yang tinggi dari trigliserida, penurunan kadar kolesterol HDL, dan peningkatan jumlah partikel LDL kecil dan padat, 
yang disebut pola subclass LDL B (Evans dkk. 1999). Sebaliknya, kadar kolesterol dan kolesterol LDL sebanding dengan yang terlihat pada subjek tanpa diabetes.

Hasil penelitian Haffner tahun 1990 telah menunjukkan bahwa karakteristik profil lipoprotein dislipidemia pada Diabetes tipe 2 mendahului timbulnya diabetes (Haffner et al 1990, Mykkänen et al. 1993) dan hadir dalam banyak kondisi di mana hanya resistensi insulin yang diamati (Ginsberg 2000).

Mekanisme pembentukan dislipidemia pada diabetes tipe 2 tetap tidak pasti, meskipun banyak faktor yang terlibat termasuk resistensi insulin, hiperinsulinemia, metabolisme asam lemak terganggu dan bahkan hiperglikemia (Evans et al, 1999). Komposisi dan jumlah lipoprotein yang berbeda diubah. Banyak penelitian menunjukkan kelebihan produksi partikel VLDL, trigliserida dan apolipoprotein B-100 (Howard 1994).

Aktivitas lipoprotein lipase ini berkurang menyebabkan turunnya katabolisme VLDL. Meskipun VLDL diperluas, kadar kolesterol LDL mungkin normal karena peningkatan proporsi partikel VLDL dimetabolisme tanpa konversi ke LDL (Howard 1987) dan ke tingkat katabolisasi frase yang disingkat LDL.

Ada peningkatan lipid exchange antara trigliserida kaya VLDL dan kedua HDL dan LDL, mungkin karena aktivitas CETP meningkat dan kelebihan VLDL (Elchebly, 1996, Ginsberg 2000). Hal ini menyebabkan penurunan kolesterol HDL dan pembentukan trigliserida yang kaya partikel HDL dan LDL. Selain itu, katabolisme HDL juga meningkat karena overaktif lipase hati (Howard 1994, De Man, 1996).

Hasil ini terjadi pada generasi partikel lipoprotein yang lebih kecil dan lebih padat dengan fungsi abnormal. Frase katabolik frase (FCR) apo A-I meningkat (Golay, 1987) yang mengarah ke tingkat kolesterol HDL yang lebih rendah (Brinton, 1994).

Partikel lipoprotein juga dimodifikasi oleh glikosilasi pada hiperglikemia. Pembersihan partikel LDL glycated berkepanjangan, dan mungkin akan lebih mudah teroksidasi, juga menyebabkan serapan yang meningkat oleh makrofag (Witztum, 1982; Bowie, 1993).

\section{MATERIAL DAN METODE}

Rancangan penelitian adalah observasional analitik dengan pendekatan cross sectional. Populasi dan sampel penelitian adalah seluruh karyawan laki-laki di perusahaan PLN sebanyak 120 orang. Teknik pengambilan sampel dilakukan dengan menggunakan purposive sampling dari kadar kolesterol menjadi 2 kelompok yaitu: normal dan abnormal. Kemudian kedua kelompok dilakukan uji Glukosa darah puasa (GDA) dan Glukosa Darah 2 jam post prandial/PP (setelah makan). Hasil kadar Glukosa darah Puasa dan Glukosa 2 jam PP akan dianalisis dengan uji Independent Sample $\mathrm{T}$ test terhadap kedua kelompok, kemudian dilanjutkan uji korelasi Pearson's untuk melihat ada tidaknya korelasi kedua kelompok penelitian terhadap kadar GDA dan 2 jam PP

Bahan pemeriksaan sampel penelitian berupa serum dan penentuan kadar Kolesterol dengan kit Kolesterol merck Glory, serta penentuan kadar Glukosa darah puasa dan 2 jam PP dilakukan dengan kit Glukosa merck Glory.

\section{HASIL PENELITIAN}

Hasil uji Independent Sample $T$ test pada kadar GDP dan 2 jam PP pada kelompok kolesterol normal dan abnormal. 


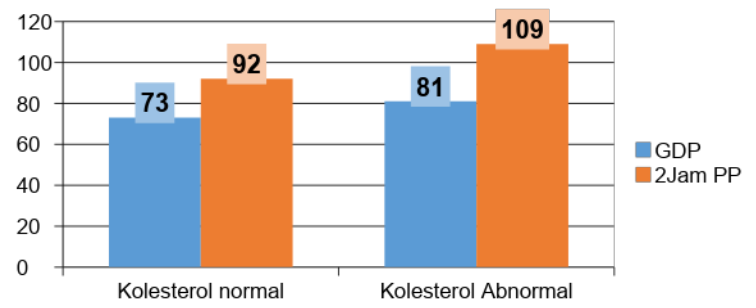

Gambar 1. Diagram Column kadar GDP dan 2 Jam PP

Pada kelompok kadar kolesterol normal dan abnormal, di mana terlihat pada kelompok kolesterol normal, nilai rata-rata GDP adalah 73 $\mathrm{mg} / \mathrm{dl}$ dan pada 2 jam PP adalah $92 \mathrm{mg} / \mathrm{dl}$, sedangkan pada kelompok kolesterol abnormal, nilai rata-rata GDP adalah $81 \mathrm{mg} / \mathrm{dl}$ dan 2 jam PP adalah $109 \mathrm{mg} / \mathrm{dl}$.

Jika dilakukan uji Independent Sample $T$ test, pada kadar GDP terlihat bahwa t hitung untuk GDP pada kolesterol normal dan abnormal dengan Equal variance assumed adalah - 1,898 dan probabilitas 0,001. Oleh karena probabilitas $<0,05$, maka rata-rata GDP kedua kelompok benar-benar berbeda, dalam artian pada kelompok kolesterol abnormal memiliki rata-rata kadar glukosa GDP lebih tinggi daripada kelompok kolesterol normal. Pada kadar 2 Jam PP terlihat bahwa t hitung pada kedua kelompok normal dan abnormal kolesterol dengan Equal variance assumed adalah - 2,052 dan probabilitas 0,007. Oleh karena probabilitas $<0,05$, maka rata-rata 2 jam PP kedua kelompok benar-benar berbeda, dalam artian pada kelompok kolesterol abnormal memiliki rata-rata kadar glukosa 2 jam PP lebih tinggi daripada kelompok kolesterol normal.

\section{Hasil uji Korelasi Pearson's kadar GDP dan 2 jam PP pada kedua kelompok normal dan abnormal kolesterol}

Tabel 1. Uji Korelasi Pearson's

\begin{tabular}{|c|c|c|c|c|}
\hline \multicolumn{5}{|c|}{ Correlations } \\
\hline & & GDP & DuaJPP & TotCholes \\
\hline \multirow[t]{3}{*}{ GDP } & Pearson Correlation & 1 & $820^{11}$ & $.262^{\mathrm{mn}}$ \\
\hline & Sig. (2-tailed) & & .000 & .005 \\
\hline & $\mathrm{N}$ & 112 & 112 & 112 \\
\hline \multirow[t]{3}{*}{ DuaJPP } & Pearson Correlation & $.820^{k \pi}$ & 1 & $.258^{\pi n}$ \\
\hline & Sig. (2-tailed) & .000 & & .006 \\
\hline & $\mathrm{N}$ & 112 & 112 & 112 \\
\hline \multirow[t]{3}{*}{ TotCholes } & Pearson Correlation & $.262^{\mathrm{kn}}$ & $.258^{\pi x}$ & 1 \\
\hline & Sig. (2-tailed) & .005 & .006 & \\
\hline & $\mathrm{N}$ & 112 & 112 & 112 \\
\hline
\end{tabular}

**. Correlation is significant at the 0.01 level (2-tailed).

Pada tabel 1 terlihat bahwa uji korelasi Pearson's pada kadar GDP sebesar $+0,262$ dengan $\mathrm{p}=0,005(\mathrm{p}<0,05)$, yang artinya kadar GDP antara kedua kelompok kolesterol normal dan abnormal berkorelasi lemah dan signifikan berbeda bermakna yang menunjukkan bahwa kadar GDP semakin meningkat akan meningkatkan kadar kolesterol. Sedangkan uji korelasi Pearson's pada kadar 2 jam PP sebesar $+0,258$ dengan $\mathrm{p}=0,006$ $(p<0,05)$, yang artinya kadar 2 jam PP antara kedua kelompok normal dan abnormal kolesterol berkorelasi lemah, namun signifikan berbeda bermakna yang menunjukkan bahwa kadar 2 jam PP semakin meningkat akan meningkatkan kadar kolesterol.

\section{PEMBAHASAN}

Hasil penelitian ini dengan uji Independent Sample $T$ test menghasilkan kadar GDP antara kedua kelompok normal dan abnormal kolesterol, ternyata berbeda bermakna di mana dinyatakan kadar GDP pada kelompok abnormal kolesterol lebih tinggi daripada kelompok normal kolesterol. Begitu pula hasil 2 jam PP antara kedua kelompok normal dan abnormal kolesterol, ternyata berbeda bermakna yang artinya kadar 2 jam PP pada kelompok abnormal kolesterol lebih tinggi daripada kelompok normal kolesterol.

Hasil penelitian ini sesuai dengan hasil penelitian Nita Garg tahun 2014 yang menyatakan "Nilai rata-rata gula darah puasa, kadar kolesterol, trigliserida dan kolesterol LDL pada kelompok 
diabetes lebih tinggi daripada kelompok nondiabetes, dan nilai kolesterol HDL ternyata lebih rendah daripada non-diabetes. Bahkan rasio kadar Cholesterol / HDL dan rasio LDL / HDL ternyata jauh lebih tinggi pada penderita diabetes daripada penderita non diabetes".

Hasil uji korelasi Pearson's juga menyatakan pada GDP terdapat korelasi meningkat positif antara kelompok normal dan abnormal kolesterol, artinya kadar GDP akan semakin meningkat pada kelompok kolesterol abnormal, dibanding kelompok kolesterol normal. Demikian pula uji korelasi Pearson's pada 2 jam PP, terdapat korelasi meningkat positif antara kadar 2 jam PP antara kelompok normal dan kelompok abnormal, kolesterol yang artinya kadar 2 jam PP akan semakin meningkat pada kelompok kolesterol abnormal, dibanding kelompok kolesterol normal.

Hasil ini sesuai juga dengan hasil disertasi Piia Simonen pada tahun 2002, di mana pada Diabetes tipe 2 berhubungan dengan penyerapan kolesterol rendah dan sintesis kolesterol meningkat. Selain itu berat badan dapat mengatur metabolisme kolesterol pada diabetes tipe 2, sehingga dapat meningkatkan berat badan lebih lanjut disertai penurunan penyerapan kolesterol. Kolesterol dan metabolisme glukosa sangat erat dan saling terkait, dan regulasi metabolisme kolesterol terkait dengan variabel yang mencerminkan resistensi insulin. Besarnya kelainan penyerapan kolesterol dan sintesis menunjukkan tingkat keparahan resistensi insulin.

Kelainan dalam metabolisme kolesterol tidak ireversibel dan penurunan berat badan adalah cara yang efisien meningkatkan metabolisme kolesterol. Selain itu, efek menguntungkan dari penurunan berat badan adalah metabolisme kolesterol bisa dilihat agak cepat, meski dalam keadaan tidak stabil. Hasil studi ini telah meningkatkan pengetahuan kita tentang metabolisme kolesterol pada Diabetes tipe 2, dan juga memberikan wawasan baru tentang efek menguntungkan dari penurunan berat badan pada obesitas sebagai pengobatan utama untuk diabetes tipe 2.

Menurut Haffner SM, 1998, Atherosclerosis adalah komplikasi utama diabetes. Studi menunjukkan bahwa penderita diabetes melitus tipe-2 yang tidak memiliki riwayat penyakit kardiovaskular, memiliki risiko yang sama menderita jantung seperti halnya pasien nondiabetes yang sebelumnya sudah ada penyakit koroner.

Menurut Fava S, 1993, terjadi peningkatan kejadian penyakit jantung akibat Diabetes, dan kasus kematian lebih besar pada pasien dengan infark miokard, maka sangat disarankan untuk menurunkan kadar lipid sebagai preventif, yang berpotensi penyakit diabetes dan jantung koroner.

\section{KESIMPULAN}

Kadar GDP dan kadar 2 jam PP akan semakin meningkat pada kelompok kolesterol abnormal dibanding kelompok kolesterol normal.

\section{REFERENSI}

Artiss JD, Zak B., 1997. Measurement of cholesterol concentration. In: Rifai $\mathrm{N}$, Warnick GR, Dominiczak MH, eds. Handbook of lipoprotein testing. Washington: AACC Press, p. 99-114

Bowie A, Owens D, Collins P, John son A, Tomkin GH., 1993. Glycosylated low density lipoprotein is more sensitive to oxidation: implications for the diabetic patient? Atherosclerosis;102:63-67.

Brinton EA, Eisenberg S, Breslow JL, 1994. Human HDL cholesterol levels are determined by apoA-I fractional catabolic rate, which correlates inversely with estimates of HDL particle size. Effects of gender, hepatic and lipoprotein lipases, 
triglyceride and insulin levels, and body fat distribution. Arterioscler Thromb;14:707720 .

Chaterjee MN, Shinde R, 2005. Textbook of medical laboratory technology. Metabolism of carbohydrates. Jaypee Brothers. Sixth edition. 266-330, Delhi, India.

De Man FH, Cabezas MC, Van Barlingen HH, Erkelens DW, de Bruin TW, 1996. Triglyceride-rich lipoproteins in noninsulin-dependent diabetes mellitus: postprandial metabolism and relation to premature atherosclerosis. Eur J Clin Invest;26:89-108.

Evans M, Khan N, Rees A., 1999. Diabetic dyslipidaemia and coronary heart disease: new perspectives. Curr Opin Lipidol;10:387-391.

Fava S, Azzopardi J, Muscat HA, Fenech FF., 1993. Factors that influence the outcome in diabetic patients with myocardial infarction. Diabetes Care; 16:1615-8.

Frank B, Stampfer J, Steven M., 2002. Elevated risk of cardiovascular disease prior to clinical diagnosis of type II Diabetes. Diabetes Care. 25: 1129-34. 8.

Ginsberg HN., 2000. Insulin resistance and cardiovascular disease. J Clin Invest;106:453-458.

Golay A, Zech L, Shi M-Z, Chiou Y-AM, Reaven GM, Chen Y-DI, 1987. High density lipoprotein (HDL) metabolism in noninsulin-dependent diabetes mellitus: measurement of HDL turnover using tritiated HDL. J Clin Endocrinol Metab;65:512-518.

Howard BV, 1994. Lipoprotein metabolism in diabetes. Curr Opin Lipidol; 5:216-220.

Haffner SM, Lehto S, Rönnemaa T, Pyörälä K, Laakso M, 1998. Mortality from coronary heart disease in subjects with type 2 diabetes and in nondiabetic subjects with and without prior myocardial infarction. N Engl J Med. 339:229-234.

Haffner SM, Stern MP, Hazuda HP, Mitchell BD, Patterson JK., 1990. Cardiovascular risk factors in confirmed prediabetic individuals. Does the clock for coronary heart disease start ticking before the onset of clinical diabetes. JAMA;263:2893-2898.

International Diabetes Federation (IDF), 2003. Access to Insulin. A report on the IDF Insulin task Force on Insulin 1994-1997.

Kahn SE, Porte D Jr., 2001. $\beta$-cell dysfunction in type 2 diabetes: pathophysiological and genetic bases. In: The metabolic and molecular bases of inherited disease. Scriver CR, Beaudet AL, Sly WS, Valle D, eds. McGraw-Hill, New York; 1407-1431.

Mykkänen L, Kuusisto J, Pyörälä K, Laakso M., 1993. Cardiovascular disease risk factors as predictors of type 2 (non-insulin-dependent) diabetes mellitus in elderly subjects. Diabetologia;36:553-559.

Nita Garg, YB Agrawal, Seema Gupta, 2014. A study of lipid profile levels in diabetics and non-diabetics taking TC/HDL ratio and LDL/HDL ratio into consideration. JIACM; 15(3-4): 192-5

Porte D Jr., 1991. Banting lecture 1990. Beta-cells in type II diabetes mellitus. Diabetes;40:166-180.

Piia Simonen, 2002. Cholesterol metabolism in type 2 diabetes. Academic dissertation, Medical Faculty of the University of Helsinki, in Auditorium 2, Biomedicum Helsinki, on December 27th, 2002, at 12 noon.

Witztum JL, Mahoney EM, Branks MJ, Fisher M, Elam R, Steinberg D., 1982. Nonenzymatic glycosylation of low-density lipoprotein alters its biologic activity. Diabetes;31:283291. 